\title{
Erva mate em foco
}

O chimarrão é uma bebida tradicionalmente consumida em vários países da América do Sul que tem como base a erva mate (Ilex paraguariensis St. Hill). Esta é originária da América do Sul, tendo como principais produtores a Argentina, Paraguai e Brasil. $\mathrm{Na}$ região Sul do Brasil, a produção ervateira tem um grande potencial econômico, social e ecológico. O mercado interno absorve $80 \%$ da produção de erva-mate, sendo $96 \%$ para o consumo do tradicional chimarrão.

O chimarrão faz parte do cotidiano do gaúcho, sendo que $80 \%$ da sociedade têm como hábito o consumo da bebida principalmente nas primeiras horas da manhã e em intervalos reservados para o descanso. Além de ser consumido em ambiente íntimo, também é tradição consumi-lo nas chamadas rodas de chimarrão, que envolve o convívio com velhas e novas amizades.

O consumo do chimarrão pode ser um hábito mais do que agradável e estimulante, uma vez que é uma importante fonte de minerais essenciais e vitaminas. Alguns estudos apontam que a erva possui efeito hipocolesterolêmico, hepatoprotetor, estimulante, diurético, antioxidante, entre outros. Os benefícios dos componentes orgânicos bioativos da llex paraguariensis têm sido amplamente difundidos, o que contribuiu para uma rápida inserção da erva mate no mercado mundial. Contudo, existem algumas limitações metodológica nos estudos para generalização segura dos achados para a população.

Nesta edição, a Revista Ciência \& Saúde conta com um estudo experimental que avaliou os efeitos do consumo de erva-mate sobre o ganho de peso e a glicemia de jejum em ratos alimentados com uma dieta hiperlipídica. Este artigo discute o papel protetor da erva mate, utilizada na forma de infusão homogeneizada na ração dos animais, que pode representar uma alternativa na pesquisa translacional para 0 manejo da obesidade.

\section{Boa Leitura!}

$$
\begin{array}{r}
\text { Prof }^{2} \text {. Dr }{ }^{2} \text {. Alessandra Campani Pizzato } \\
\text { Professora do Curso de Nutrição da } \\
\text { FAENFI/PUCRS }
\end{array}
$$

